\title{
Dacron Reconstruction of Aortic Aneurysm and Long Term Patients Evolution
}

\author{
CRISTINA TUDORAN, MARIANA TUDORAN*, TUDOR CIOCARLIE, CATALINA GIURGI-ONCU, DANA VELIMIROVICI*, \\ MARIA RADA, DELIA BERCEANU-VADUVA \\ University of Medicine and Pharmacy Victor Babes Timisoara, 2 Efimie Murgu Sq., 300041, Timisoara, Romania
}

\begin{abstract}
Aortic aneurysm ( $A A)$ and especially dissecting aneurism (DAA) represent life threatening medical conditions and vascular reconstruction surgery with the insertion of a vascular prosthetic grafts is often required to save patients life. In this paper we debate over the long term outcome of 23 patients who underwent five to eight years ago an aortic reconstruction surgery with insertion of Dacron grafts. They attended, during 2018, the emergency room of the County Emergency Hospital Pius Brinzeu of Timisoara in terms of patency complications of the prosthesis. Despite slight dilatation of the Dacron graft and of the native aorta, presence of mural thrombi and/or progress of aortic regurgitation, their evolution was satisfactory, without severe complications.
\end{abstract}

Keywords: Dacron grafts, aortic aneurysm, pseudoaneurysm, vascular reconstruction surgery

The first vascular Dacron (polyethylene terephthalate fiber) prosthesis was tailored by DeBakey in the 1950s and was used to replace a descending aortic aneurysm. Since the mid-1970s, these grafts are widely used in cardiac and vascular surgery and it has been estimated that over 1.2 million Dacron prosthesis have been implanted worldwide. Despite their general success, the inability to reproduce the elasto-mechanical properties and the compliance of the native aorta, lead to several hemodynamic and biological alterations with impact on the cardiovascular physiology. Such concerns have been debated in several surgical and experimental studies which report over long term complications of the Dacron grafts [1-3]. The connection between the aorta and the artificial materials, as well as the suture places, are usually the origin of these complications $[4,5]$. Dilation, occurrence of paraanastomotic pseudoaneurysms or even aneurysms, thrombosis and, in rare cases, infection are the most frequently recorded complications [5-8]. These reports have been followed by research efforts in the tissue engineering field, aiming to improve the biomimetic proprieties of the grafts, with impact on the long-term outcome of patients undergoing aortic replacement $[9,10]$.

We debate in this paper over the long term evolution of patients with history of AA or DAA who underwent aortic reconstruction with Dacron grafts. They were evaluated by means of contrast enhanced angio-computertomography. The condition of the graft was assessed revealing, in most cases, good patency.

\section{Experimental part}

Synthetic vascular grafts, including expanded poly(ethylene terephthalate) (Dacron ${ }^{\circledR}$ ) or poly(tetrafluoroethylene) (ePTFE), have been largely available since the mid-1970s and represent the most widely employed vascular substitutes in the cardiovascular surgery [11]. Their large availability and ease of use have allowed an extensive application of these conduits in a wide spectrum of vascular pathologies, including aneurysms of large vessels and atherosclerosis of peripheral territories [12].

Dacron (polyethylene terephthalate) is the trademark for a polyester fiber used to manufacture vascular, especially aortic prosthesis, largely used in the cardiovascular, but also in the vascular surgery. Dacron is a condensation polymer, obtained from ethylene glycol and terephthalic acid. Its properties include high tensile strength, high resistance to stretching, both wet and dry, and good resistance to degradation by chemicals and to abrasion $[13,14]$. Most contemporary vascular Dacron grafts are in the shape of a tube, they are made either of knitted or of woven Dacron fabric, each type having its advantages and limits, (fig. 1).

On the other hand, modifications of the existing polyurethanes, to improve their mechanical characteristics, have been experimented. Addition of a gelatin-based hydrophilic layer to the hydrophobic core of polyurethane determined significant changes in the core-sheath structures, and consequently, in their mechanical properties, leading to the generation of scaffolds with tissuelike viscoelasticity, increased compliance and improved

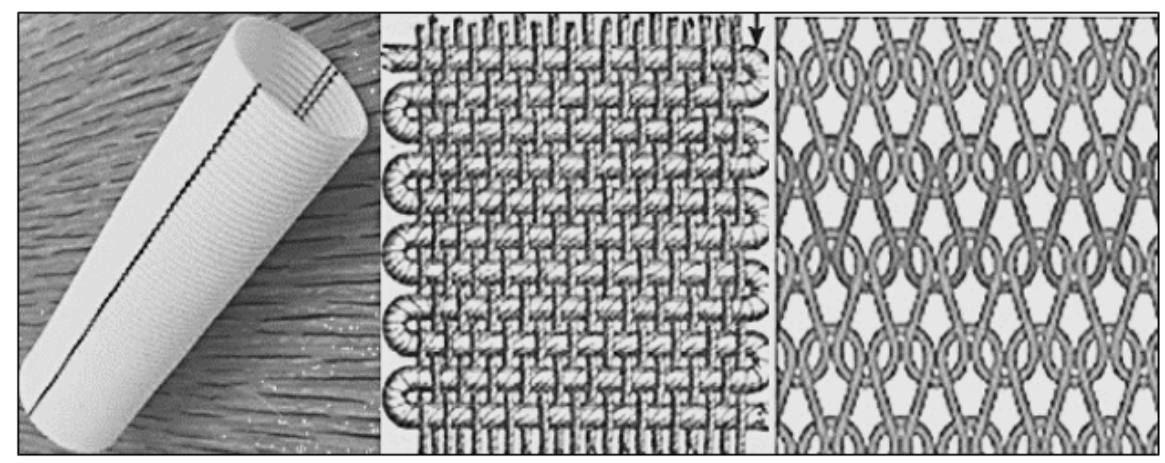

Fig. 1. Dacron aortic prostesis (left); Wowen (midle) versus Knitten (right) structure of the wall

\footnotetext{
*email: mariana.tudoran@gmail.com, Phone: +40722310302; danavelimirovici@yahoo.com,Phone: +40723211190
} 


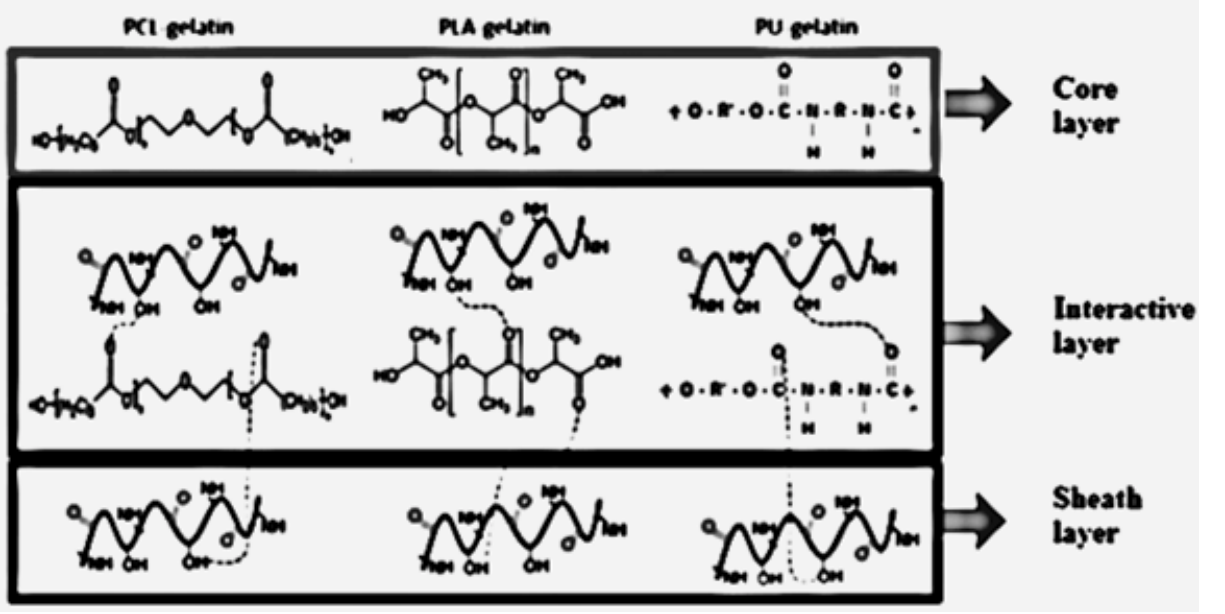

Fig. 2. Schematic representation of core layers in the coaxially electrospun nanofibrous system; Highly Compliant Vascular Grafts with Gelatin-Sheathed Coaxially Structured Nanofibers

resistance to pressure [9]. A schematic representation of these materials is illustrated in figure 2. These grafts are superior in terms of elastomechanical properties of polymers as polycaprolactone or polylactic acid, which are added to improve biocompatibility [10].

Patients group: this study was conducted on 23 patients, 14 men and 9 women, aged between 55 and 71 years, mean age $62.24 \pm 7.18$ years, who attended the emergency care unit of County Emergency Hospital Pius Brinzeu of Timisoara presenting themselves in terms of complications of the prosthesis, during J anuary-December 2018, for various medical reasons was observed. All of them had history of AA, DAA or aortic coarctation and underwent aortic reconstruction surgery with implantation of a Dacron graft. After a detailed anamnesis and a rigorous clinical exam, they underwent echocardiography. All echocardiographic examinations were performed with an Acuson Sequoia C 512 echocardiograph, by the same echocardiographist in order to avoid inter-observer differences. On the echocardiography, after a regular exam of cardiac morphology and function, we assessed the dimensions of the ascendant aorta, aortic arch and aortic valves. Contrast enhanced computerangiography was performed in all cases, in order to document the structure and patency of the aorta and, especially, of the Dacron graft, and to evidence if there are any complications. Peripheral Doppler ultrasonography was performed in nine cases.

\section{Statistical methods}

Data analysis was performed using SPSS v.25 (Statistical Package for the Social Sciences, Chicago, IL, USA). Continuous variables were presented as mean and standard deviation (SD) or median and interquartile range $(I Q R)$, and categorical variables were presented as frequency and percentages. The results of the normality test (Shapiro-Wilk) showed a non-Gaussian distribution, reason why we continued to use nonparametric tests. To compare continuous variables, we applied Mann-Whitney $U$ test. A p value of less than 0.05 was considered to indicate a statistically significant difference.

The study was approved by the Ethics Committee of our hospital and all patients signed a written informed consent.

\section{Results and discussions}

All twenty-three patients included in our study had history of AA, DAA or, in one case, aortic coarctation. All of them underwent cardiovascular surgery five to eight years ago with aortic reconstruction and implantation of a Dacron graft. Nine of them had prosthesis of the ascendant aorta, one had a replacement of the ascendant and of the aortic arch and thirteen had grafts of the descendent segment including aortic bifurcation in three cases. There were 14 men and 9 women, aged between 55 and 71 years, mean age $62.24 \pm 7.18$ years. They attended the emergency care unit for complains like angina, rhythm disturbances, abdominal colic, uncontrolled hypertension or claudication. Clinical characteristics, the main indications for aortic reconstruction and the time since surgery, associated diseases and risk factors, are illustrated in table 1. In addition to major cardiovascular risk factors (high blood pressure, dyslipidemia, diabetes, smoking), hyperuricemia is currently considered a cardiovascular risk factor, frequently associated with metabolic syndrome [1517].

Table 1

CLINICAL CHARACTERISTICS, ASSOCIATED CONDITIONS AND RISK FACTORS OF THE STUDY GROUP

\begin{tabular}{|c|c|c|c|}
\hline \multicolumn{2}{|l|}{ Clinical characteristics } & \multicolumn{2}{|c|}{ Associated conditions and risk factors } \\
\hline Age (years) & $62.24 \pm 7.18$ years & Systemic hypertension & $12(52.17 \%)$ \\
\hline \multirow{2}{*}{$\begin{array}{r}\text { Gender: male } \\
\text { female }\end{array}$} & \multirow{2}{*}{$\begin{array}{l}14-60.86 \% \\
9-39.13 \%\end{array}$} & Coronary artery disease & $9(39.13 \%)$ \\
\hline & & Peripheral artery disease & $5(21.73 \%)$ \\
\hline $\mathrm{BMI}\left(\mathrm{Kg} / \mathrm{m}^{2}\right)$ & $26.8(24.3-29.1)$ & Aortic regurgitation & $14(60.86 \%)$ \\
\hline Heart rate (b/min) & $65(60-70)$ & Diabetes mellitus & $7(30.43 \%)$ \\
\hline SBP (mmHg) & $139(135-150)$ & COPD & $4(17.39 \%)$ \\
\hline DBP (mmHg) & $89.5(85-101)$ & CKD & $11(47.83 \%)$ \\
\hline \multicolumn{2}{|c|}{ Indication for aortic reconstruction } & Metabolic syndrome & $5(21.73 \%)$ \\
\hline \multirow{3}{*}{$\begin{array}{l}\text { - Aortic aneurysm (AA) } \\
\text { - Dissecting AA } \\
\text { - Aortic coarctation }\end{array}$} & \multirow{3}{*}{$\begin{array}{l}15(65.21 \%) \\
7(30.43 \%) \\
1(4.34 \%)\end{array}$} & Hypercholesterolemia & $12(52.17 \%)$ \\
\hline & & Hypertriglyceridemia & $7(30.43 \%)$ \\
\hline & & Hyperuricemia & $5(21.73 \%)$ \\
\hline Time since surgery & $4.6(5-8)$ years & Smoking & $11(47.83 \%)$ \\
\hline
\end{tabular}

Legend: BMI -body mass index; SBP -systolic blood pressure; DBP -diastolic blood pressure; COPD -chronic obstructive pulmonary disease; CKD -chronic kidney disease. 

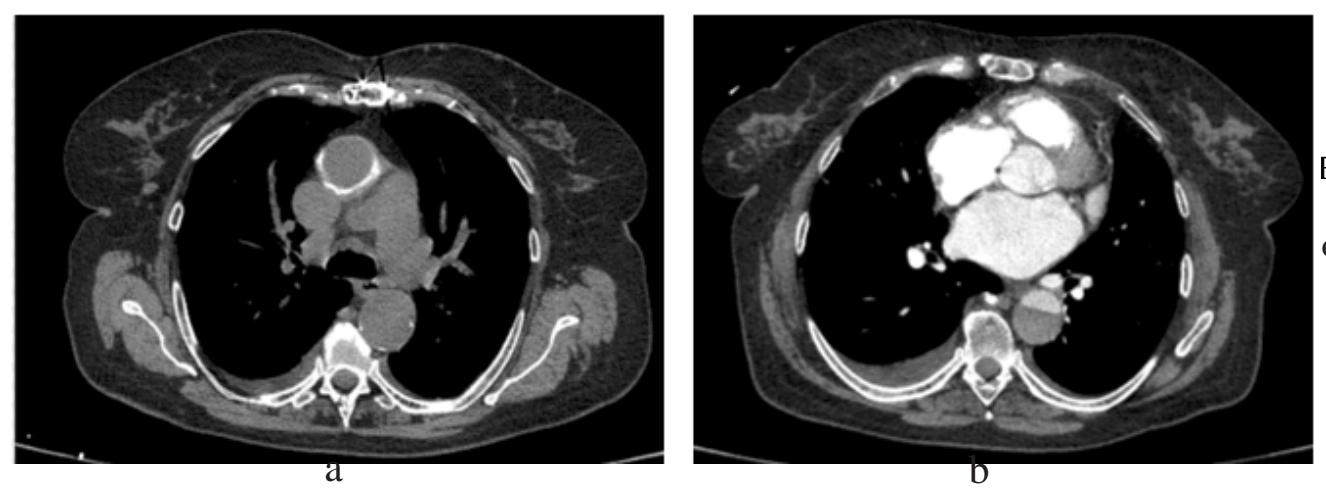

Fig. 3. Computerangiography of the aorta in a female patient evidencing the ascendant aorta (a) reconstructed with a Dacron graft and (b) the still dissected, but thrombosed descending segment

The AA represented the most frequent indication for aortic reconstruction. There were $6 \mathrm{AA}$ of the ascendant aorta and 9 of the descendant segment. DAA was the second indication. The dissection was localized to ascendant aorta (Type 2) in 3 cases, it comprised the entire thoracic aorta in 2 cases (Type 1) and was limited to the abdominal aorta (sub-renal segment) in 2 patients.

The echocardiography revealed slight dilatation of the reconstructed aortic segment $(p=0.035)$ comparing to previous available measurements. This finding was detected also in the remaining native aorta. There was evidence of left ventricular hypertrophy in 13 subjects ( 9 had this aspect also before surgery) and moderate aortic regurgitation was evidenced in 11 patients.

Contrast enhanced computerangiography of the entire aorta was the method of choice used in our study, for the assessment of Dacron grafts patency and for evidencing the presence of complications like aneurysm or pseudoaneurysm, thrombosis and fistulas. Although there was evidence of slight dilatation of the graft, as well as of the native aorta, none of our patients had para-anastomotic pseudoaneurysms, aneurysms or fistulas. In the 2 cases with DAA of the entire thoracic aorta (Type 1 DeBakey), where a replacement with a Dacron prosthesis of the ascendant segment was performed, the remaining descendant aorta was in good condition, with a patent lumen and thrombosis between the dissecting flap and the aortic wall. In figure 3 there are images of the graft placed on the ascendant segment and of the partially thrombosed descendant segment.

There are several opinions about the mechanisms responsible for occurrence of these complication after the reconstructive surgery of the aorta with Dacron grafts. Spandaccio et al debated over the concept of compliance mismatch between the graft and the native aorta, which could be responsible for the occurrence of complications like dilation or aneurysm, para-anastomotic pseudoaneurysm and mechanical failure, often requiring additional surgery [1]. They consider that the region of contact between the aorta and the artificial materials, like Prolene, used for sutures, and Dacron, is a locus minoris resistentiae which is usually, the basis for the occurrence of pseudoaneurysms. They reported an incidence of 2 to $6 \%$ after aortic repair, that can be associated with lifethreatening complications such as rupture, fistulas or thrombosis. Furthermore, the insertion of synthetic material into the arterial system triggers the inflammation of neighboring tissues, induces endothelial dysfunction and favors thrombosis [18-21].

Several attempts have been made to improve the biocompatibility of these prosthesis. A modality was to use an albumin-coating on the knitted Dacron aortic grafts to increase their impermeability. In his study, Brancherau et all concluded that albumin-coated Dacron prosthesis are reliable for aortic replacement, the results being comparable to the uncoated ones [11]. More recent researches debate over improving the mechanical characteristics of the existing polyurethanes by adding a gelatin-based hydrophilic sheath to the hydrophobic core of polyurethane [9]. This could increase the resistance and compliance of polyurethane, offering a tissue-like viscoelasticity. Newly developed bioresorbable polymers, as polycaprolactone or polylactic acid, (fig. 2,) demonstrate improved elastomechanical properties and superior biocompatibility due to their architecture in which this polymer is structured (matrix-like nano-fibrilles) and to the nature of the material. Other possibilities are the impregnation of grafts with Silver Acetate, Silver Acetate + Triclosan and the heparin-coating or the use of xenografts. Actual trends are the researches in tissue engineering, in order to develop vascular surrogates, simulating the biological and physical properties of native vessels, in order to be used in the cardiovascular surgery.

\section{Conclusions}

Although there was evidence of mural thrombi and slight dilatation of the prosthesis, but also of the native aorta, our patients with aortic reconstruction by using Dacron grafts had a satisfactory long-term evolution. Further efforts to perfect aortic grafts, either by improving existing polyurethanes or by creating new bioresorbable materials, as well as the progress of vascular tissue bioengineering, will overcome the limitations associated with current Dacron prosthesis.

\section{References}

1. SPADACCIO, C., NAPPI, F., AL-ATTAR, N., SUTHERLAND, F.W., ACAR, C., NENNA, A., TROMBeTtA, M., CHELLO, M., RAINER, A., J. Cardiovasc. Transl. Res., 9, 2016; p. 334.

2. TAKAMI, Y., KATO, W., TAJ IMA, K., FUJI, K., Interactive Cardiovascular and Thoracic Surgery, 14, nr. 5, 2012, p. 529.

3. DAVID, T.E., ARMSTRONG, S., MANLHIOT, C., MCCRINDLE, B.W., FEINDEL, C.M., J. Thorac. Cardiovasc. Surg., 145, nr. 3, 2013, p. 22. 4. MULDER, E.J., VAN BOCKEL, J.H., MAAS, J., VAN DEN AKKER, P.J., HERMANS, J., Arch. Surg., 133, nr. 1, 1998, p. 45.

5. BOUCHART, F., DUBAR, A., TABLEY, A., LITZLER, P.Y., HAASHUBSCHER, C., SOYER, R., The Annals of Thoracic Surgery, 70, nr. 5, 2000, p. 1488.

6. GARIBOLDI, V., GRISOLI, D., KERBAUL, F., GIORGI, A., RIBERI, A., METRAS, D. MESANA, T.G., COLLART, F., Interactive CardioVascular and Thoracic Surgery, 6, nr. 1, 2007, p. 47.

7. CLAGETT, G.P., SALANDER, J.M., EDDLEMAN, W. L., CABELLON, S. J r.,YOUKEY, J.R., OLSON, D.W., HUTTON, J.E.J r., RICH, N.M., Surgery, 93, nr. 1, 1983, p. 9.

8. BERCEANU VADUVA, D.M., VELIMIROVICI, D.E., BERCEANU VADUVA, M.M., STANGA, L., PETRESCU, H., RADA, M., CIPU, D., BERCEANU VADUVA, B.M., RADULESCU, M., Mat. Plast., 55, no. 3, 2018, p. 372 
9. MORENO, M.J., AIJI, A., MOHEBBI-KALHORI, D., RUKHLOVA, M., HADJ IZADEH, A., BUREAU, M.N, J. Biomed. Mater. Res. B. Appl. Biomater., 97, nr. 2, 2011, p. 201.

10. NAGIAH, N., J OHNSON, R., ANDERSON, R., ELLIOTT, W., TAN, W., Langmuir., 31, nr. 47, 2015, p. 12993.

11. FERRARI, G., BALASUBRAMANIAN, P., TUBALDI, E., GIOVANNIELLO, F., AMABILI, M., J ournal of Biomechanics, no. 86, 2019, p.132

12. BRANCHEREAU, A., RUDONDY, P., GOURNIER, J.P., ESPINOZA, $H$, Ann. Vasc. Surg., 4, nr. 2, 1990, p. 138.

13. JAYENDIRAN, R., NOUR, B.M., J ournal of the Mechanical Behavior of Biomedical Materials, 78, 2018, p. 329.

14. TUBALDI, E., PAIDOUSSIS, M.P., AMABILI, M., J. Biomech. Eng., 140, nr. 6, 2018.

15. VELIMIROVICI, D. E., RADA, M., BERCEANU VADUVA, D.M., VELIMIROVICI, M. D., DRAGAN, S., DUDA SEIMAN, M., CIPU, D., DUDA SEIMAN, C., STANCU, A., BERCEANU VADUVA, M., Rev. Chim.(Bucharest), 69, no. 11, 2018, p. 3018.
16. DUSE, A. O., BERCEANU VADUVA, D., NICOLOV, M., TRANDAFIRESCU, C., BERCEANU VADUVA, M., CEVEI, M., HEGHES, A., Rev. Chim.(Bucharest), 68, no. 6, 2017, p. 1234.

17. RADA, M., BERCEANU-VADUVA, D., VELIMIROVICI, M., DRAGAN, S., DUDA-SEIMAN, D., BERCEANU-VADUVA, M., DUDA-SEIMAN, C., TUDORAN, M., VELIMIROVICI, D., Rev. Chim.(Bucharest), 70, no. 3, 2019, p. 1062.

18. RYLSKI, B., MILEWSKI, R.K., BAVARIA, J.E., BRANCHETTI, E., VALLABHAJ OSULA, P., SZETO, W.Y., DESAI, N.D., Ann. Thorac. Surg., 99, 2015, p. 88.

19. JANASZEK-SITKOWSKA, H., MICHALOWSKA, I., SZPAKOW SKI, E., KABAT, M., Nadcisnienie Tetnicze, 13, nr. 5, 2009, p. 320.

20. ETZ, C.D., HOMANN, T., SILOVITZ, D., BODIAN, C.A., LUEHR, M., Gabriele DI LUOZZO, G., PLESTIS, K. A., GRIEPP, R.B., Ann. Thorac. Surg.,84, 2007, p. 1206

21. TUDORAN, M., TUDORAN, C., Niger. J. Clin. Pract., 19, nr. 6, 2016, p. 831.

Manuscript received: 21.03 .2019 